\title{
Quarterly Management Document FY20, 2nd Quarter, Physics-based Creep Simulations of Thick Section Welds in High Temperature and Pressure Applications
}

Thomas M Lillo, Wen Jiang

April 2020

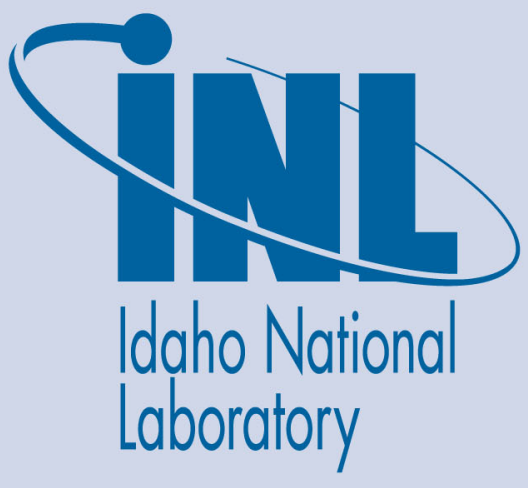

The INL is a U.S. Department of Energy National Laboratory operated by Battelle Energy Alliance 


\section{Quarterly Management Document FY20, 2nd Quarter, Physics-based Creep Simulations of Thick Section Welds in High Temperature and Pressure Applications}

Thomas M Lillo, Wen Jiang

April 2020

Idaho National Laboratory Idaho Falls, Idaho 83415

http://www.inl.gov

Prepared for the U.S. Department of Energy Office of Fossil Energy Under DOE Idaho Operations Office Contract DE-AC07-05ID14517 
Quarterly Management Document - FY20, $2^{\text {nd }}$ Quarter, Physics-based Creep Simulations of Thick Section Welds in High Temperature and Pressure Applications

Document \# INL/EXT-20-58120

\begin{tabular}{|c|c|c|c|c|}
\hline $\begin{array}{l}\text { WBS Element } \\
\text { C.B.10.02.02.4 } \\
0\end{array}$ & $\begin{array}{l}\text { Project Title } \\
\text { Physics-based Creep Simulations of } \\
\text { Thick Section Welds in High } \\
\text { Temperature and Pressure } \\
\text { Applications }\end{array}$ & $\begin{array}{l}\text { Contract Numbe } \\
\text { FEAA90 }\end{array}$ & $\begin{array}{l}\text { Contract Start } \\
10 / 01 / 17\end{array}$ & $\begin{array}{l}\text { Contract End } \\
09 / 30 / 2020\end{array}$ \\
\hline \multicolumn{2}{|c|}{$\begin{array}{l}\text { Performer Name and Address } \\
\text { Thomas Lillo } \\
\text { Idaho National Laboratory } \\
\text { P.O. Box } 1625 \\
\text { Idaho Falls, ID } 83415\end{array}$} & & \multicolumn{2}{|c|}{ Thomas Lillo } \\
\hline
\end{tabular}

BUDGET AND COST REPORT

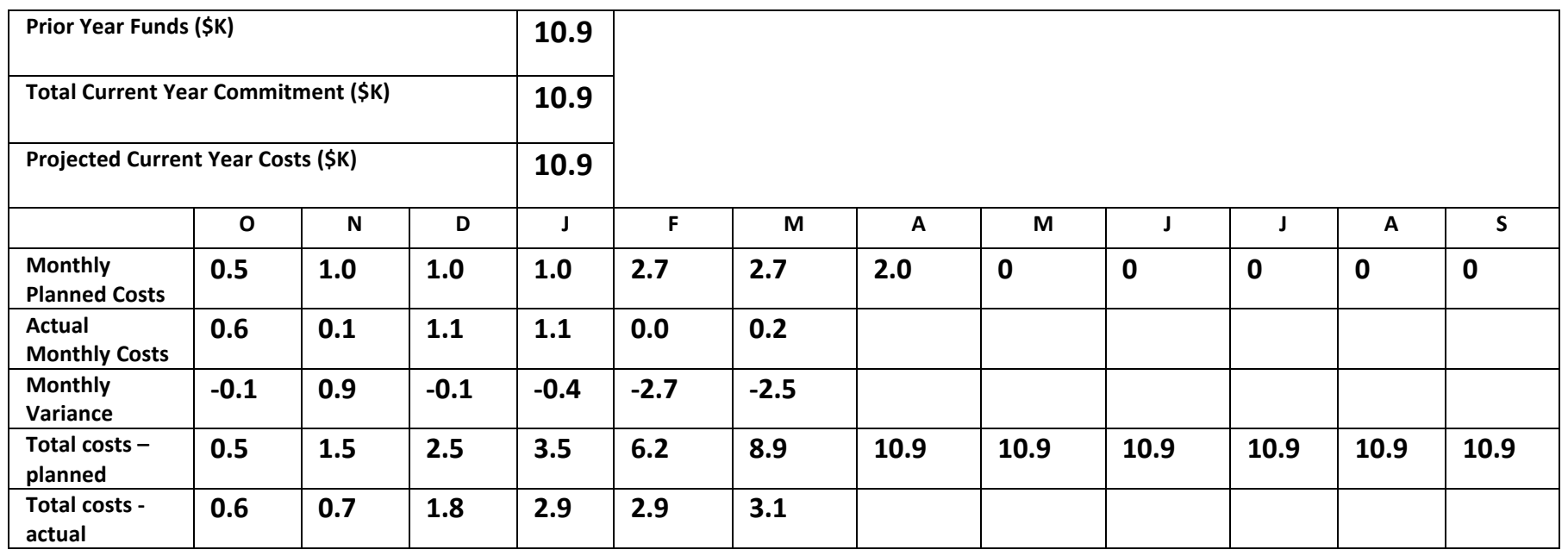

MILESTONE REPORT

\begin{tabular}{|c|l|l|l|l|}
\hline $\begin{array}{c}\text { Milestone } \\
\text { Designation }\end{array}$ & \multicolumn{1}{|c|}{ Milestone Description } & Due Date & $\begin{array}{c}\text { Revised Due } \\
\text { Date }\end{array}$ & $\begin{array}{c}\text { Completion } \\
\text { Date }\end{array}$ \\
\hline A & Evaluate current MOOSE capabilities & $09 / 30 / 2015$ & & $09 / 30 / 2015$ \\
\hline B & Complete Alloy 617 weld characterization & $10 / 30 / 2015$ & & $11 / 18 / 2015$ \\
\hline C & Receipt of Alloy 740H plates & $10 / 30 / 2015$ & & $11 / 05 / 2015$ \\
\hline D & Complete welds in Alloy 740H & & & \\
\hline
\end{tabular}




\begin{tabular}{|c|c|c|c|c|}
\hline $\mathrm{E}$ & Characterize Alloy $740 \mathrm{H}$ welds & $02 / 01 / 2016$ & $09 / 30 / 2016$ & $9 / 02 / 2016$ \\
\hline $\mathrm{F}$ & Creep model development - Stage 1 & $09 / 30 / 2016$ & & $9 / 30 / 2016$ \\
\hline G & Creep Model Development - Stage 2 & $8 / 29 / 2017$ & $2 / 28 / 2019$ & $1 / 15 / 2019$ \\
\hline $\mathrm{H}$ & Calibration of Secondary creep - Alloy 617 & $9 / 30 / 2017$ & $3 / 31 / 2019$ & Eliminated \\
\hline I & Stress Drop Tests & $2 / 01 / 2017$ & $5 / 31 / 2018$ & $6 / 28 / 2018$ \\
\hline $\mathrm{J}$ & $\begin{array}{l}\text { Characterization of creep failure } \\
\text { mechanisms }\end{array}$ & $4 / 01 / 2017$ & $04 / 30 / 2018$ & $5 / 04 / 2018$ \\
\hline $\mathrm{K}$ & $\begin{array}{l}\text { Secondary creep calibration for welds - } \\
\text { Alloy } 617\end{array}$ & $5 / 30 / 2018$ & $4 / 15 / 2019$ & Eliminated \\
\hline $\mathrm{L}$ & $\begin{array}{l}\text { Creep model development-Completion of } \\
\text { Stage } 3\end{array}$ & $8 / 30 / 2018$ & $8 / 16 / 2019$ & $9 / 9 / 2019$ \\
\hline $\mathrm{M}$ & $\begin{array}{l}\text { Creep simulation of a welded joint in Alloy } \\
740 \mathrm{H}\end{array}$ & $9 / 30 / 2018$ & $08 / 31 / 2020$ & \\
\hline $\mathrm{N}$ & $\begin{array}{l}\text { Validation of creep simulation model via an } \\
\text { Alloy } 740 \mathrm{H} \text { weld consisting of refined } \\
\text { microstructure }\end{array}$ & $9 / 15 / 2018$ & $09 / 30 / 2020$ & \\
\hline
\end{tabular}

TECHNICAL HIGHLIGHTS

Milestone M, "Creep simulation of a welded joint in Alloy $740 \mathrm{H}$ "

Calibration of the model continued using the experimental creep data for the base metal. A few errors in the execution of the model were discovered and corrected. The model was then calibrated using base metal creep data from the highest temperature $\left(800^{\circ} \mathrm{C}\right)$ and the lowest temperature $\left(700^{\circ} \mathrm{C}\right)$ creep data with the intent of comparing model simulations to creep data from $750^{\circ} \mathrm{C}$. Figures 1 and 2 show the model simulations for $700^{\circ} \mathrm{C}, 413 \mathrm{MPa}$ and $800^{\circ} \mathrm{C}, 200 \mathrm{MPa}$, respectively.

Most notably in Fig. 1, the model simulates the primary and secondary creep behavior quite well but deviates considerably in the tertiary regime - tending to overestimate the creep strain and, thus, underestimating the creep rupture life by about a factor of 2 (however, the simulation was not run to failure - it is estimated that the simulated creep life will be significantly shorter than the experimental creep life). In the world of creep data, this is not unexpected due to variations in microstructure and experimental testing complexities. However, since the model was calibrated using this experimental data, it would intuitively seem that a better fit to the experimental data should be obtained. The tertiary regime has been an issue since the physical mechanism responsible for the transition to tertiary creep has not been definitively identified (Lillo, T.M., Wright, R.N., "The Onset of Tertiary Creep in Alloy 617", proceedings of the 2015 PVP Pressure Vessel and Piping Conference, Boston, MA, July 19-23, 2015.). We have chosen to use a damage model described by Shen (C. Shen, Modeling Long-term Creep Performance for Welded Nickel-base Superalloy Structures for Power Generation Systems, DOE/NETL Cooperative Agreement DE-FE0024027, 2015) and consists of damage due to dislocation motion as well as damage due to diffusional processes (see, the $3^{\text {rd }}$ Quarter Management Report, FY19 for further details). The damage parameter for the $700^{\circ} \mathrm{C}, 413 \mathrm{MPa}$ simulation also has been plotted in Fig. 1 (the gold line), and, again, in Fig. 3 by itself. The damage parameter is largely linear throughout about 
half of the creep life and then starts to accelerate toward the end of life (i.e., deviates from linearity) which is intuitively expected. However, at high values of the damage parameter, i.e., toward the end of life, the rate of damage accumulation in the simulation decreases. This is not expected as the damage increases the effective stress (damage equates to loss of load-bearing cross-sectional area in the Shen damage model) in the gage section of the creep specimen and thus the damage rate is expected to accelerate as the specimen reaches endof-life. The result of the decreasing damage rate is manifested as a decrease in the creep rate at the end of life as shown in Fig. 1. It is not clear at this time the cause behind this behavior but it is thought this is not correct and efforts are underway to understand and, if necessary, correct this behavior in the model.

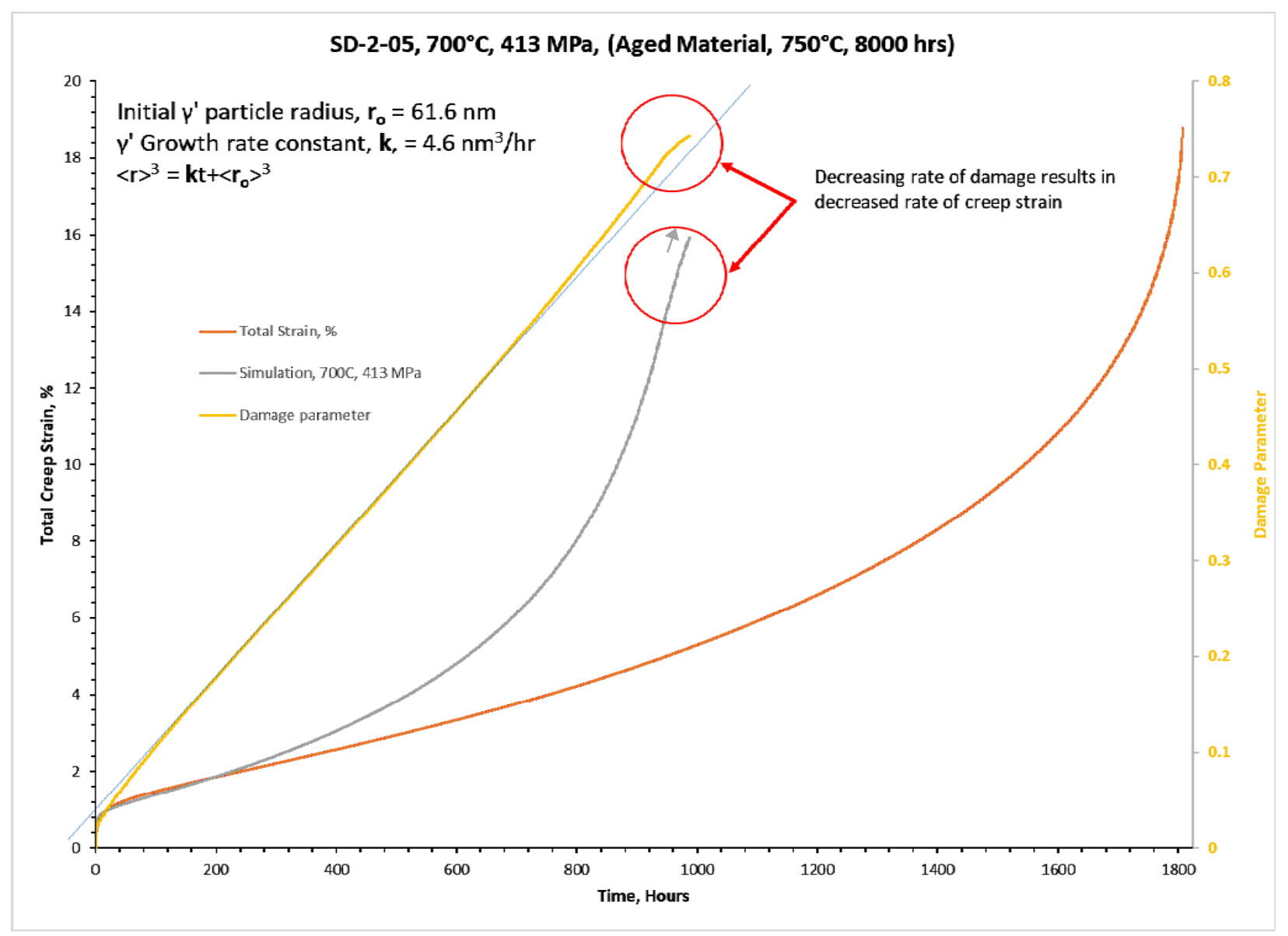

Figure 1. Plots of the experimental creep behavior of the base metal at $700^{\circ} \mathrm{C}$ (orange curve) with the simulation from the model overlaid (grey curve). The damage parameter from the simulation is also plotted (gold curve). The base metal material for sample SD-2-05 was aged for 8000 hrs at $750^{\circ} \mathrm{C}$ prior to fabrication of the creep specimen.

At $800^{\circ} \mathrm{C}$, the model, again, predicts primary and secondary creep quite well, Fig. 2 . In this case, however, the simulation significantly underestimates the tertiary creep strain. The simulation was not run to high values of the damage parameter, which indicates end-of-life, and the damage parameter exhibits linear behavior over the time of the simulation. The damage parameter in this simulation does not exceed about 0.37 - compared to about 0.74 for the simulation in Fig. 1.

After calibration using the experimental data in Figs. 1 and 2, the model was used to simulate the creep behavior at $750^{\circ} \mathrm{C}$ and $305 \mathrm{MPa}$, Fig. 4 . The model predicts primary and secondary creep behavior under these 
conditions quite well when compared to the two experimental datasets at these conditions. (The experimental data does show considerable variation in creep behavior with the creep life varying by about $25 \%$ or a factor of 1.25.) However, again, the creep strain associated with tertiary creep is underestimated. Again, the simulation was not run to end-of-life (i.e., high damage values) but it would appear the model predicts a value for end-oflife that is approximately a factor of 2 greater than the actual creep life of the experimental creep tests. The damage parameter shows deviation from linearity in Fig. 4 (gold curve), but, again, the simulation was only run to a maximum damage parameter value of about 0.55 (in theory, a damage parameter of 1 indicates failure and end-of-life).

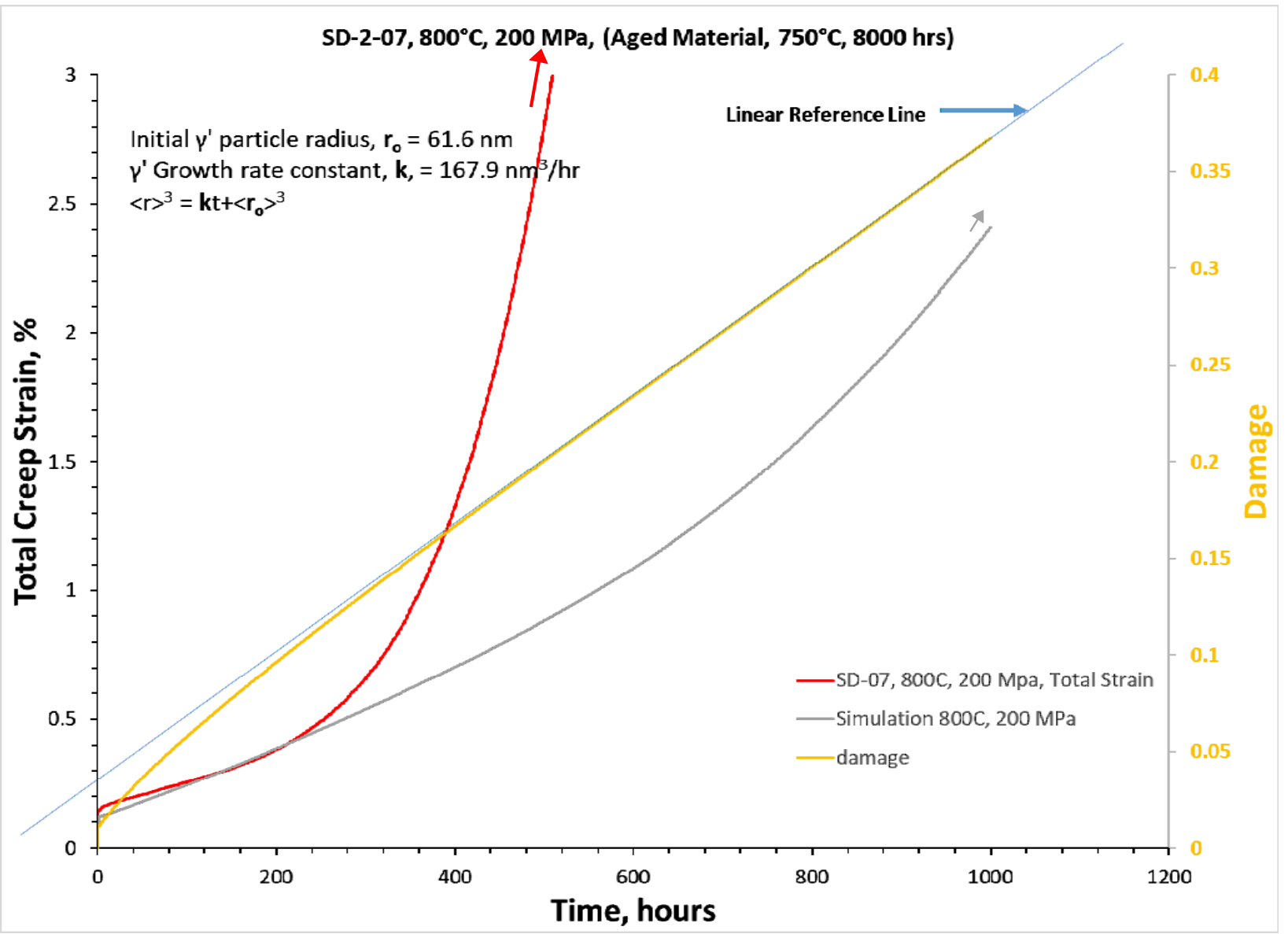

Figure 2. Plot of the experimental creep behavior at $800^{\circ} \mathrm{C}$ and $200 \mathrm{MPa}$ for base metal (red curve) and the simulated creep behavior (grey curve). The damage parameter is also plotted in this figure (gold curve). The material for the base metal sample, SD2-07, was aged for 8000 hrs at $750^{\circ} \mathrm{C}$ prior to fabrication of the creep specimen. 


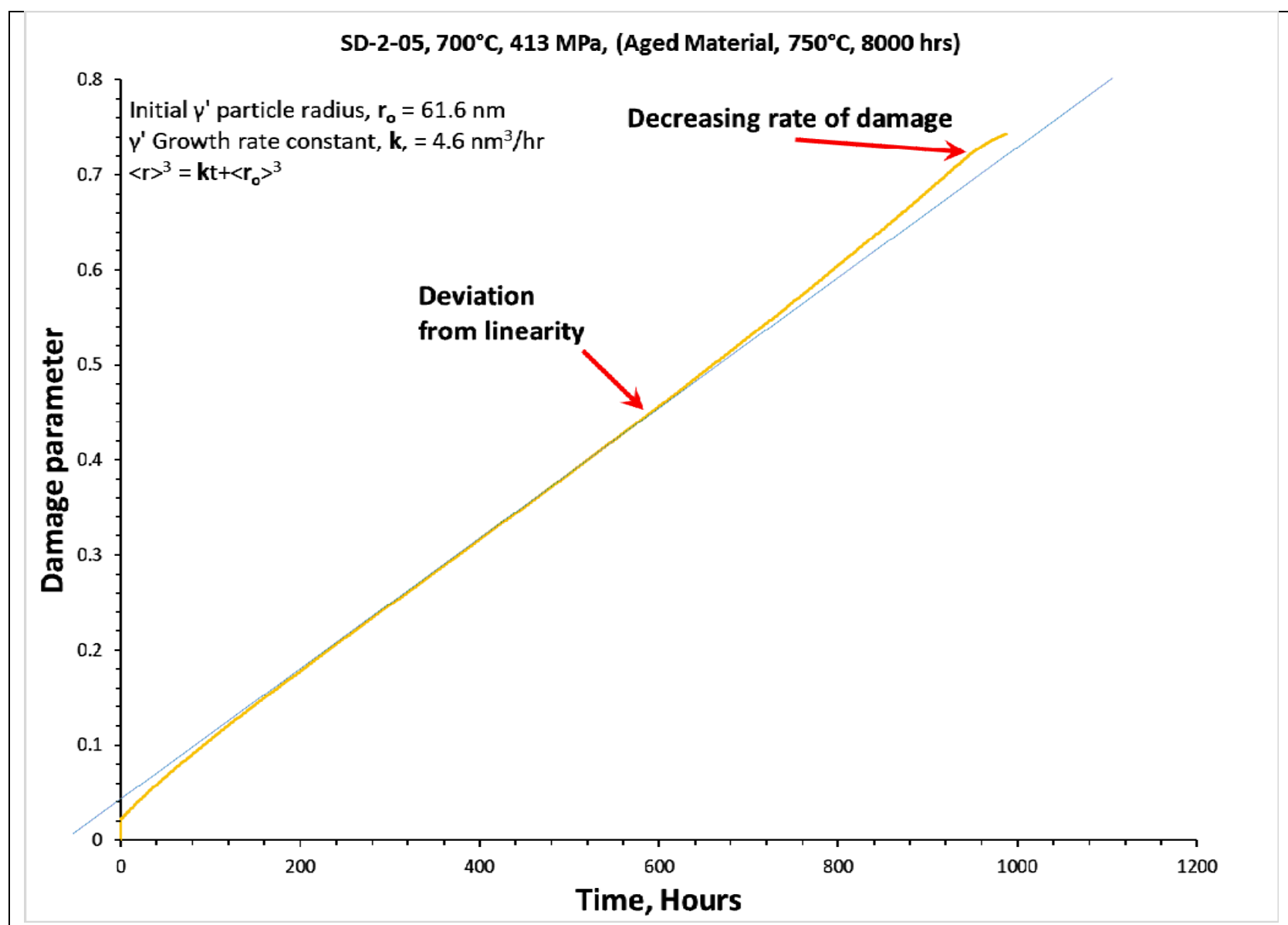

Figure 3. Plot of the damage parameter for the simulation of $700^{\circ} \mathrm{C}$ and $413 \mathrm{MPa}$. The damage parameter deviates from linearity later in the simulated creep life, as expected, but also exhibits a decreasing damage rate at the very end of life which is not expected. 


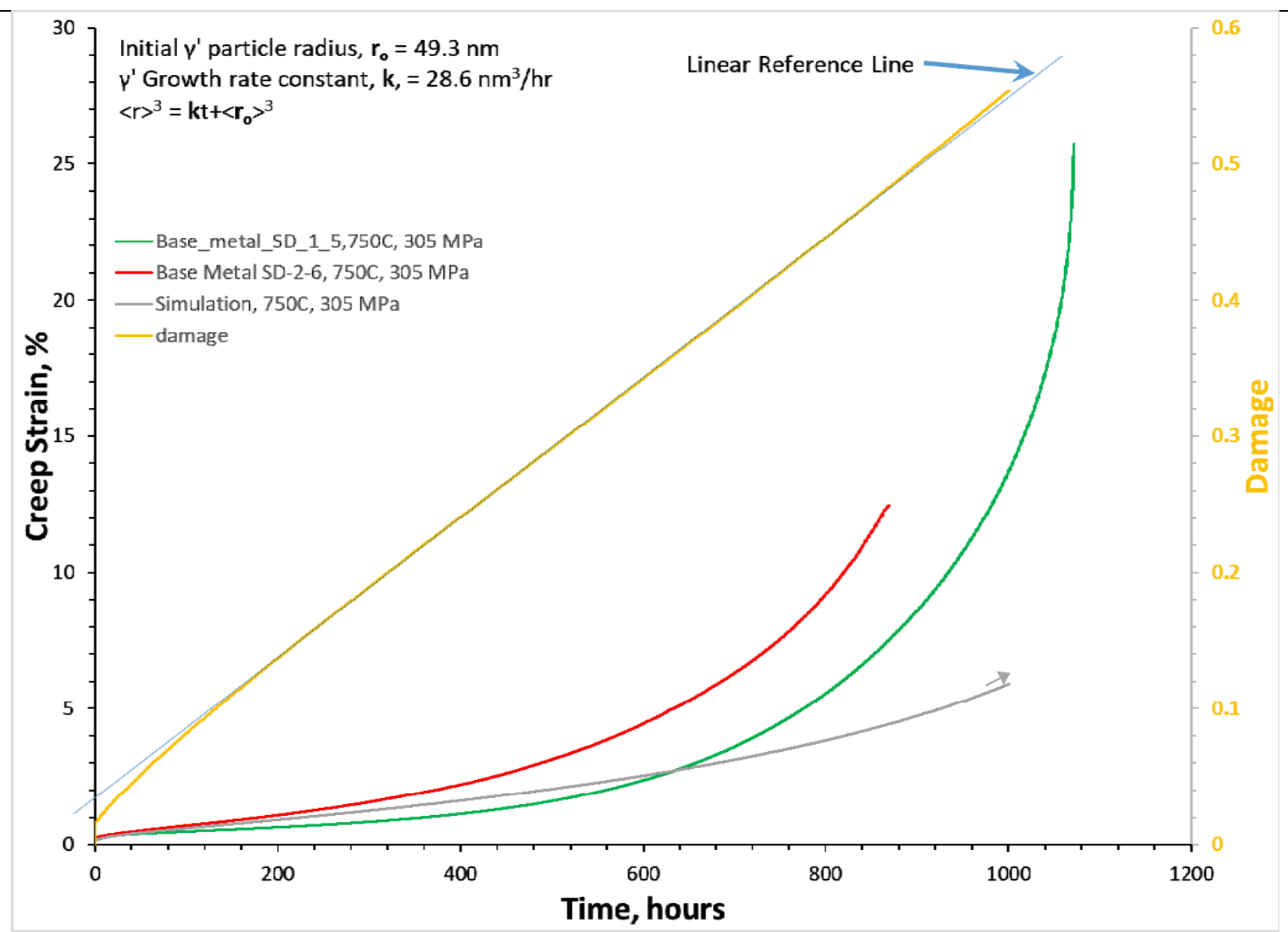

Figure 4. Plots of the experimental creep curves, SD-1-5 and SD-2-6, at $750^{\circ} \mathrm{C}$ and $305 \mathrm{MPa}$, green and red curves, respectively. The simulated creep curve (grey curve) is also plotted. Finally, the damage parameter is included in the figure.

Overall, the model simulates primary and secondary creep under the various experimental creep conditions. Figures 1,2 and 4 seem to indicate that damage is overestimated at $700^{\circ} \mathrm{C}, 413 \mathrm{MPa}$ and underestimated at the 750 and $800^{\circ} \mathrm{C}$ creep conditions. The influence of diffusion increases with test temperature, which, experimentally, ranges from about $0.64 \mathrm{~T}_{\mathrm{MP}}$ to about $0.70 \mathrm{~T}_{\mathrm{MP}}$, and can be expected to influence the contribution of diffusion to the simulation. Since the model simulates primary and secondary creep well for each test temperature, it is likely the influence of diffusion on the damage parameter evolution is not quite as it should be. A closer look at the influence of diffusion on the evolution of the damage parameter will be carried out early next quarter. Additionally, changes to the calibration methodology will be explored, e.g., calibration using the two sets of creep data taken at 800 and $750^{\circ} \mathrm{C}$ versus the current calibration using the 800 and $700^{\circ} \mathrm{C}$ data.

Completion of this task is now targeted for $08 / 31 / 2020$.

Milestone N, "Validation of creep simulation model via an Alloy $740 \mathrm{H}$ weld consisting of refined microstructure"

No progress on this task during the $2^{\text {nd }}$ quarter of FY20.

The completion date of this task is now targeted for $09 / 30 / 2020$ 


\section{ISSUES}

Tertiary creep remains a hurdle to be overcome in the simulation. The reason for this is due the ambiguous mechanism resulting in the transition to tertiary creep. It is likely a physical mechanism is responsible for the transition to tertiary creep and it remains to be seen whether the damage parameter evolution approach will prove a satisfactory description of the mechanism(s) responsible for the transition to tertiary creep. At this point, we will look at this to the extent possible (i.e., within the limits of the remaining funds) and then move on to simulating the all-weld metal creep tests. After this, the simulation of cross weld creep tests will be a combination of the base metal behavior and the weld metal behavior based on a rule-ofmixtures approach based on the fractions of base metal and weld metal in the gage section of the creep specimen.

\begin{tabular}{|l|l|}
\hline Report Prepared By & Date \\
\hline Thomas M. Lillo and Wen Jiang & $04 / 28 / 2020$ \\
\hline
\end{tabular}

